\title{
Changes in weed infestation in corn crops in southwestern region of Poland in 1963-2013 years
}

\author{
Zmiany w zachwaszczeniu kukurydzy \\ w południowo-zachodnim rejonie Polski w latach 1963-2013
}

\author{
Hanna Gołębiowska*, Tomasz Snopczyński, Krzysztof Domaradzki, Henryka Rola
}

\begin{abstract}
Summary
The changes presented in the floristic list revealed that in the years 1963-1972 the following weed species dominated in the studied corn crops: Chenopodium album, Echinochloa crus-galli, Elymus repens, Cirsium arvense, Sinapis arvensis, Galinsoga parviflora and Polygonaceae. This weed composition was mainly affected by a rotation and perennial cultivation of corn for silage. A similar infestation occurred in the years 1973 to 1982, but cover indexes were higher for Ch. album, E. crus-galli, and Amaranthus retroflexus and lower for perennial species. Large-area cultivation of maize and widespread use of herbicides were the major factors that affected that situation. In the years 1983 to 1992 A. retroflexus appeared also fairly frequently in the list of segetal flora. More species diversity compared to previous periods was recorded and it was caused by transformation of ownership in agriculture. In the years 1993-2002 simple tillage systems, application of monocultures and restoring fallow land affected on weed infestation of corn crops. This pattern of weed composition continued in the years 2003-2013 but with greater intensity of thermophilic species.
\end{abstract}

Key words: corn; weed infestation; monitoring; changes; phytosociological stability; cover index

\section{Streszczenie}

Zmiany na liście florystycznej uprawy kukurydzy w latach 1963-1972 wykazały dominację: komosy białej, chwastnicy jednostronnej, perzu właściwego, ostrożenia polnego, gorczycy polnej, żółtlicy drobnokwiatowej oraz rdestów, na którą głównie wpływało stosownie płodozmianów oraz wieloletnia uprawa kukurydzy w użytkowaniu kiszonkowym. Podobny stan zachwaszczenia występował w latach 1973-1982, jednak współczynniki pokrycia dla komosy białej, chwastnicy jednostronnej i szarłatu szorstkiego były wyższe, a niższe dla gatunków wieloletnich, co wynikało z wielkoobszarowej uprawy kukurydzy i powszechnego stosowania herbicydów. W latach 1983-1992 na liście flory segetalnej dominował również szarłat szorstki. Notowano większe zróżnicowanie gatunkowe na co głównie oddziaływały przekształcenia własnościowe. W latach 1993-2002 na stan zachwaszczenia upraw kukurydzy wpłynęło stosowanie uproszczeń uprawowych, monokultury oraz zagospodarowywanie odłogów. Podobny stan zachwaszczenia utrzymywał się w latach 2003-2013, jednak z większym udziałem gatunków ciepłolubnych.

Słowa kluczowe: uprawa kukurydzy; zmiany zachwaszczenia; monitoring; stałość fitosocjologiczna; współczynnik pokrycia

Instytut Uprawy Nawożenia i Gleboznawstwa - Państwowy Instytut Badawczy

Zakład Herbologii i Technik Uprawy Roli

Orzechowa 61, 50-540 Wrocław

*corresponding author: h.golebiowska@iung.wroclaw.pl 


\section{Wstęp / Introduction}

Zbiorowiska chwastów segetalnych towarzyszące uprawie kukurydzy przez wiele lat charakteryzowały się względną stabilizacją. Sprzyjało to wykształcaniu barier biotycznych, w tym oddziaływań allelopatycznych między poszczególnymi gatunkami, jak i rośliną uprawną, co w dużej mierze stabilizowało równowagę w tych agrobiocenozach (Bochenek i Hołdyński 1996; Solarz 2007). Wzrost powierzchni zasiewów kukurydzy kiszonkowej dokonujący się pod koniec lat 70. XX wieku, zmiany technologii uprawy w kierunku użytkowania na ziarno oraz intensyfikacja produkcji związana $\mathrm{z}$ obecną koniunkturą ekonomiczną zaburzyły ten stan równowagi. Nastąpiło ubożenie zbiorowisk chwastów towarzyszących kukurydzy, a znikome cechy rzędu lub klasy, czyli typowej agrofitocenozy można obecnie wyodrębnić tylko w gospodarstwach drobnopowierzchniowych (Kuźniewski 1988; Latowski i Jackowski 2011).

Bioróżnorodność zbiorowisk chwastów determinowana czynnikami siedliskowymi powoduje, że w uprawie kukurydzy na żyznych glebach kompleksów pszennych liczniej występują gatunki azotolubne i zasadolubne, jak: szarłat szorstki (Amaranthus retroflexus L.), tobołki polne (Thlaspi arvense L.), maruna bezwonna (Triplerospermum inodorum L.), a na ubogich glebach kompleksów żytnich: rdesty, fiołek polny (Viola arvensis Murr.) i rumian polny (Anthemis arvensis L.), jako rośliny wskaźnikowe gleb ubogich w wapń (Gołębiowska 2007; Woźnica 2008).

Podstawowym źródłem zachwaszczenia kukurydzy są nagromadzone w glebie diaspory, określane jako glebowy bank nasion. Liczba gatunków oraz ilość nasion w glebie zależą od jej: rodzaju, odczynu, właściwości chemicznych i fizycznych oraz agrotechniki. Z tego względu częste wprowadzanie uproszczeń uprawowych, jak i monokultury kukurydzy mogą zasadniczo zmieniać dotychczasowy stan zachwaszczenia wynikający z warunków uprawy opartych na orce i płodozmianie (Jędruszczak i wsp. 2007).

W ostatnich latach na skład gatunkowy tych zbiorowisk duży wpływ wywierają: zmiany klimatyczne - wyższe temperatury w porównaniu ze średnimi wieloletnimi, wzrost usłonecznienia w maju i czerwcu, co w konsekwencji doprowadziło do wcześniejszej o 10 dni wegetacji roślin zwłaszcza w rejonie południowo-zachodnim (Kwiatkowska-Anioł 1998; Kozyra 2004).

\section{Hipoteza badawcza}

Stan i skład gatunkowy w zbiorowiskach chwastów segetalnych towarzyszących uprawie kukurydzy na przestrzeni lat ulega ciągłym przekształceniom pod wpływem zmieniających się czynników agroekologicznych - biotycznych i abiotycznych, jak również konkurencyjnego oddziaływania gatunków ekspansywnych, często obcego pochodzenia. Znajomość tych zmian może służyć modyfikowaniu metod regulacji zachwaszczenia i przyjęciu strategii ich ograniczania w uprawie kukurydzy.

Celem badań było przedstawienie zmian stanu zachwaszczenia w ujęciu dekadowym zachodzących w latach 1963-2013, przeprowadzonych na postawie zdjęć fitosocjologicznych.

\section{Materiały i metody / Materials and methods}

Obserwacje stanu zachwaszczenia w zasiewach kukurydzy prowadzono w rejonie południowo-zachodniej Polski w latach 1963-2013. Badania w głównej mierze opierały się na danych zebranych metodą zdjęć fitosocjologicznych, wykonanych w Zakładzie Ekologii i Zwalczania Chwastów, przekształconego w 2007 roku w Zakład Herbologii i Technik Uprawy Roli, Instytutu Uprawy Nawożenia i Gleboznawstwa - Państwowego Instytutu Badawczego w Puławach.

W badanym okresie na różnych stanowiskach glebowych makroregionu południowo-zachodniego, prowadzono obserwacje zachwaszczenia metodą Braun-Blanqueta (Banaszak i Wiśniewski 2003), które pozwoliły wyodrębnić kilka charakterystycznych agrocenoz w ujęciu dekadowym. Wykonano łącznie 1564 zdjęcia fitosocjologiczne. Rejestrowano wszystkie gatunki występujące na powierzchni zdjęcia $(10 \mathrm{~m} \times 10 \mathrm{~m})$. Dla każdego gatunku obliczono współczynnik pokrycia z uwzględnieniem stopni ilościowości oraz stałość fitosocjologiczną (Banaszak i Wiśniewski 2003).

Współczynnik pokrycia (W.p.) obliczano według wzoru:

$$
\begin{aligned}
& \text { suma średnich procentów przeciętnego } \\
& \text { pokrycia gatunku na danej powierzchni } \\
& \text { W.p. }=\frac{\text { we wszystkich zdjęciach fitosocjologicznych }}{\text { ogólna liczba zdjęć }} \times 100
\end{aligned}
$$

Stałość fitosocjologiczna (S) to efekt pojawiania się danego gatunku w płatach roślinnych - fitocenozach, na określonej powierzchni, wyrażony w skali 5-stopniowej podanej w metodyce opracowanej przez Pawłowskiego (1972).

Zebrane wyniki badań opracowano oddzielnie dla każdego dziesięciolecia, określając: łączną liczbę gatunków występujących we wszystkich zdjęciach fitosocjologicznych, ich stałość występowania oraz współczynniki pokrycia powierzchni dla gatunków jedno- i dwuliściennych oraz innych, a wśród nich dla jednorocznych, wieloletnich, a także wyodrębniając gatunki dominujące charakterystyczne dla badanych okresów. Nazwy własne gatunków pojawiających się na liście florystycznej w kolejnych dziesięcioleciach podano za Mirkiem i wsp. (1995).

\section{Wyniki i dyskusja / Results and discussion}

Badania nad zagrożeniem występowania gatunków segetalnych w podstawowych uprawach rolniczych prowadzone w latach 1963-1972 w makroregionie południowozachodnim pozwoliły ustalić stan zachwaszczenia na plantacjach kukurydzy. Wyznaczenie stopni stałości fitosocjologicznej i współczynnika pokrycia na podstawie 107 zdjęć fitosocjologicznych pozwoliło wytypować gatunki o najwyższym nasileniu. Stwierdzono, że w grupie gatunków dwuliściennych największe zagrożenie stanowiła stale obecna w zbiorowisku komosa biała (Chenopodium album L.) o najwyższym współczynniku pokrycia 
wynoszącym 2039,7 oraz lokalnie, na słabszych kompleksach glebowych, gorczyca polna (Sinapis arvensis L.) i żółtlica drobnokwiatowa (Galinsoga parviflora Cav.). Spośród 13 gatunków dwuliściennych wieloletnich obecnych w zbiorowiskach w latach badań największe zagrożenie stanowił dość powszechny ostrożeń polny [Cirsium arvense (L.) Scop.], którego szkodliwość wynika z wysokiej siły konkurencji nawet, gdy pojawia się w niewielkich liczebnościach. Pozostałe gatunki dwuliścienne jednoroczne pojawiały się rzadko oraz sporadycznie i w niskim pokryciu, chociaż szarłat szorstki (A. retroflexus), chaber bławatek (Centaurea cyanus L.), przetacznik perski (Veronica persica L.), czy rdesty (Polygonum spp.) oraz z jednoliściennych - włośnice (Setaria spp.), utrzymywały się w zasiewach aż do zbioru (tab. 2). W grupie 7 gatunków jednoliściennych jednorocz-nych notowano najwyższe współczynniki pokrycia dla chwastnicy jednostronnej [Echinochloa crus-galli (L.) P. Beauv.], natomiast spośród wieloletnich, bez względu na stanowisko glebowe, dużym zagrożeniem był perz właściwy [Elymus repens (L.) Goud.] o współczynniku pokrycia wynoszącym 858,2 i stałości fitosocjologicznej (S) w stopniu III. Natomiast w grupie gatunków rzadkich i sporadycznych o znikomym pokryciu w zbio-rowisku zaznaczyło swoją obecność 14 gatunków, w tym 5 gatunków wieloletnich (tab. 3).

W następnym dziesięcioleciu, na który przypadały lata 1973-1982 zachodziło wiele istotnych zmian w dotychczasowym stanie zachwaszczenia. Na podstawie przeprowadzonych 179 zdjęć fitosocjologicznych stwierdzono zmniejszenie różnorodności zbiorowisk roślinności segetalnej w wyniku redukcji liczby gatunków z 62 do 49 taksonów, w tym również ograniczenie liczebności gatunków wieloletnich, zarówno dwuliściennych, jak i jednoliściennych (tab. 2). W grupie gatunków dwuliściennych zwiększyła swoją dominację komosa biała, dla której notowano wzrost wartości współczynnika pokrycia do 2325,9, a na słabych glebach płowych nadal dość licznie utrzymywała swoją obecność żółtlica drobnokwiatowa oraz pojawiła się dotąd niespotykana przytulia czepna (Galium aparine L.) o wysokiej stałości fitosocjologicznej w stopniu III i współczynniku pokrycia wynoszącym 917,3. Gatunki dwuliścienne jednoroczne takie, jak szarłat szorstki czy gwiazdnica pospolita [Stellaria media (L.) Vill.], dotychczas pojawiające się rzadko lub sporadycznie i w niewielkich pokryciach, w omawianym okresie znacznie zwiększyły swoją stałość i nasilenie w zbiorowiskach (tab. 4).

Wśród 5 gatunków jednoliściennych jednorocznych notowano najwyższe współczynniki pokrycia jedynie dla chwastnicy jednostronnej o współczynniku pokrycia wynoszącym 1444,9, znacznie częściej spotykanej w zasiewach kukurydzy w porównaniu $\mathrm{z}$ poprzednim dziesięcioleciem, o czym świadczy wysoki stopień stałości fitosocjologicznej (tab. 2). Natomiast w tym rejonie widocznie spadło zagrożenie perzem właściwym, rzadko spotykanym $\mathrm{w}$ zasiewach $\mathrm{i}$ w niewielkim pokryciu. $\mathrm{Na}$ liście chwastów sporadycznie towarzyszących kukurydzy obecnych było 12 taksonów, w tym 5 gatunków wieloletnich (tab. 4).
W badanej dekadzie, w stosunku do minionego okresu, zwiększyły swoją dominację komosa biała oraz chwastnica jednostronna, stale i najliczniej występujące w zasiewach, co było efektem: intensyfikacji produkcji, wzrostu areału uprawy kukurydzy i powszechnym wykorzystywaniem herbicydów głównie z udziałem atrazyny (tab. 1).

W kolejnym dziesięcioleciu przypadającym na lata 1983-1992 największy wpływ na różnicowanie się zbiorowisk chwastów segetalnych wywarł dalszy wzrost uprawy kukurydzy w technologii kiszonkowej oraz powszechne wykorzystywanie środków chwastobójczych. Skutkiem tego, na podstawie przeprowadzonych 264 zdjęć fitosocjologicznych, było dalsze ubożenie listy florystycznej zbiorowisk chwastów segetalnych do 45 gatunków, w tym dalsze ograniczenie liczebności gatunków wieloletnich głównie dwuliściennych (tab. 2). W grupie chwastów o najwyższej konkurencji ciągle dominuje komosa biała i chwastnica jednostronna notowane prawie we wszystkich zdjęciach fitosocjologicznych, a także szarłat szorstki (A. retroflexus) ze współczynnikiem pokrycia wynoszącym 771,5 i wysokim stopniem stałości fitosocjologicznej, co daje podstawę, by uznać go za gatunek często obecny w tych zbiorowiskach. Natomiast wysycenie płodozmianów rzepakiem ozimym i zbożami spowodowało na żyźniejszych glebach dość liczne pojawianie się w dużym pokryciu gatunków krzyżowych, a zwłaszcza samosiewów rzepaku. W porównaniu $\mathrm{z}$ poprzednim okresem rzadziej obserwowano obecność żółtlicy drobnokwiatowej, dla której wartość współczynnika pokrycia spadła do 98,8 (tab. 5). W grupie gatunków jednoliściennych jednorocznych znacznie wzrosły współczynniki pokrycia dla chwastnicy jednostronnej w porównaniu z poprzednim dziesięcioleciem. Wzrosła również liczba gatunków ze stałością fitosocjologiczną w stopniach od $\mathrm{V}$ do II, z 7 do 11 taksonów oraz ubożenie różnorodności w grupie pozostałych gatunków $\mathrm{z}$ listy florystycznej zarówno jednorocznych, jak i wieloletnich.

Najbardziej niekorzystnym okresem oddziałującym na stan zachwaszczenia kukurydzy w rejonie południowozachodnim były lata 1993-2002, na ktory złożyły się przekształcenia własnościowe $\mathrm{w}$ rolnictwie wielkoobszarowym oraz gwałtowny spadek powierzchni uprawy kukurydzy na kiszonkę (tab. 1).

Na podstawie przeprowadzonych 470 zdjęć fitosocjologicznych odnotowano wzrost różnorodności w zbiorowisku do 53 gatunków, z ograniczeniem liczebności gatunków wieloletnich (tab. 2). W grupie chwastów o wysokiej konkurencji w zasiewach kukurydzy zaczyna dominować chwastnica jednostronna o najwyższym współczynniku pokrycia wynoszącym 1783,7 przed komosą białą i szarłatem szorstkim, dla którego jednak zanotowano niższą stałość i pokrycie niż w latach 1983-1992. W porównaniu z poprzednim okresem wzrosła wartość współczynnika pokrycia dla fiołka polnego (V. arvensis) z wartości 71,3 do 332,1 (tab. 6). W latach badań znacznie zwiększyła się liczba gatunków, dla których notowano stałość fitosocjologiczną od V do II stopni. Należy również zwrócić uwagę na liczniejszą obecność bylicy pospolitej (Artemisia vulgaris L.) oraz jej wzrost pokrycia w zasiewach. 
Tabela 1. Powierzchnia uprawy kukurydzy w Polsce w latach 1963-2013

Table 1. Cultivation area of corn crop in Poland in 1963-2013 years

\begin{tabular}{l|c|c|c|c|c}
\hline \multicolumn{1}{c|}{$\begin{array}{l}\text { Dekady } \\
\text { Decade }\end{array}$} & \multicolumn{4}{c}{ Średnie z badanych okresów - Average of the studied periods } \\
\cline { 2 - 6 } & $1963-1972$ & $1973-1982$ & $1983-1992$ & $1993-2002$ & $2003-2013$ \\
\hline $\begin{array}{l}\text { Uprawa kukurydzy na kiszonkę } \\
\text { Cultivation of corn for silage [tys. ha] }\end{array}$ & 329481 & 609942 & 325830 & 148049 & 368980 \\
\hline $\begin{array}{l}\text { Uprawa kukurydzy na ziarno } \\
\text { Cultivation of corn for grain [tys. ha] }\end{array}$ & 27157 & 97713 & 82041 & 154269 & 418996 \\
\hline $\begin{array}{l}\text { Udział kukurydzy na ziarno i kiszonkę } \\
\text { w ogólnej strukturze zasiewów } \\
\begin{array}{l}\text { Structure of corn for grain and silage } \\
\text { in the total crop structure [\%] }\end{array}\end{array}$ & 0,8 & 4,1 & 1,3 & 3,7 & 5,7 \\
\hline
\end{tabular}

Tabela 2. Wybrane wskaźniki bioróżnorodności zbiorowisk chwastów w uprawie kukurydzy w latach 1963-2013

Table 2. Selected biodiversity indicators of weed community in corn depending on different soil cultivation systems in 1963-2013

\begin{tabular}{|c|c|c|c|c|c|c|c|c|c|c|}
\hline \multirow{2}{*}{$\begin{array}{l}\text { Wskaźniki bioróżnorodności zbiorowisk } \\
\text { Indicators of weed infestation }\end{array}$} & \multicolumn{10}{|c|}{ Średnie z badanych okresów - Average of the studied periods } \\
\hline & \multicolumn{2}{|c|}{$1963-1972$} & \multicolumn{2}{|c|}{$1973-1982$} & \multicolumn{2}{|c|}{ 1983-1992 } & \multicolumn{2}{|c|}{ 1993-2002 } & \multicolumn{2}{|c|}{$2003-2013$} \\
\hline $\begin{array}{l}\text { Liczba zdjęć fitosocjologicznych } \\
\text { Number of phytosociological pictures }\end{array}$ & \multicolumn{2}{|c|}{107} & \multicolumn{2}{|c|}{179} & \multicolumn{2}{|c|}{264} & \multicolumn{2}{|c|}{470} & \multicolumn{2}{|c|}{444} \\
\hline $\begin{array}{l}\text { Średnia liczba gatunków w zdjęciu } \\
\text { fitosocjologicznym - Average number } \\
\text { of species per phytosociological record }\end{array}$ & \multicolumn{2}{|c|}{62} & \multicolumn{2}{|c|}{49} & \multicolumn{2}{|c|}{45} & \multicolumn{2}{|c|}{53} & \multicolumn{2}{|c|}{51} \\
\hline $\begin{array}{l}\text { w tym: - including: } \\
\text { - jednoliścienne jednoroczne } \\
\text { annual monocotyledonous }\end{array}$ & \multicolumn{2}{|c|}{7} & \multicolumn{2}{|c|}{5} & \multicolumn{2}{|c|}{5} & \multicolumn{2}{|l|}{3} & \multicolumn{2}{|l|}{4} \\
\hline $\begin{array}{l}\text { - jednoliścienne wieloletnie } \\
\text { perennial monocotyledonous }\end{array}$ & \multicolumn{2}{|c|}{2} & \multicolumn{2}{|c|}{1} & \multicolumn{2}{|c|}{1} & \multicolumn{2}{|l|}{1} & \multicolumn{2}{|l|}{1} \\
\hline $\begin{array}{l}\text { - dwuliścienne jednoroczne } \\
\text { annual dicotyledonous }\end{array}$ & \multicolumn{2}{|c|}{40} & \multicolumn{2}{|c|}{35} & \multicolumn{2}{|c|}{33} & \multicolumn{2}{|c|}{43} & \multicolumn{2}{|c|}{41} \\
\hline $\begin{array}{l}\text { - dwuliścienne wieloletnie } \\
\text { perennial dicotyledonous }\end{array}$ & \multicolumn{2}{|c|}{12} & \multicolumn{2}{|c|}{8} & \multicolumn{2}{|c|}{5} & \multicolumn{2}{|l|}{5} & \multicolumn{2}{|l|}{4} \\
\hline - inne - others & 1 & & - & & 1 & & 1 & & 1 & \\
\hline $\begin{array}{l}\text { Liczba gatunków sporadycznych } \\
\text { i rzadkich - Numer of species of sporadic } \\
\text { and rare occurrence }\end{array}$ & 14 & & 12 & & 4 & & 8 & & 4 & \\
\hline Gatunki dominujące - Dominat weed species & W.p. & $\mathrm{S}$ & W.p. & $\mathrm{S}$ & W.p. & $\mathrm{S}$ & W.p. & $\mathrm{S}$ & W.p. & $\mathrm{S}$ \\
\hline $\begin{array}{l}\text { Chwastnica jednostronna } \\
\text { Echinochloa crus-galli (L.) P. Beauv }\end{array}$ & 1300,2 & III & 1444,9 & IV & 1560 & IV & 1783,7 & $\mathrm{~V}$ & 1704,2 & $\mathrm{~V}$ \\
\hline Komosa biała - Chenopodium album L. & 2039,7 & $\mathrm{~V}$ & 2325,9 & $\mathrm{~V}$ & 2823 & $\mathrm{~V}$ & 1523,5 & IV & 1512,1 & $\mathrm{~V}$ \\
\hline $\begin{array}{l}\text { Suma współczynników pokrycia } \\
\text { Sum of weed infestation rate }\end{array}$ & 333 & & 3770 & & 438 & & 3307 & & 3216 & \\
\hline
\end{tabular}

S - stałość fitosocjologiczna - phytosociological stability, W.p. - współczynnik pokrycia - cover index

Tabela 3. Stan zachwaszczenia upraw kukurydzy gatunkami segetalnymi na podstawie 107 zdjęć fitosocjologicznych w makroregionie południowo-zachodnim Polski wykonanych w latach 1963-1972

Table 3. Weed infestation of corn according to phytosociological pictures in southwestern macro-region of Poland performed in $1963-1972$

\begin{tabular}{c|l|c|c}
\hline Lp. - No. & \multicolumn{1}{|c|}{ Gatunek - Species } & W.p. & S \\
\hline 1 & \multicolumn{1}{|c|}{2} & 3 & 4 \\
\hline 1 & komosa biała - Chenopodium album L. & 2039,7 & V \\
\hline 2 & chwastnica jednostronna - Echinochloa crus -galli (L.) P. Beauv. & 1300,2 & III \\
\hline 3 & źłtlica drobnokwiatowa - Galinsoga parviflora Cav. & 974,3 & II \\
\hline 4 & perz właściwy - Elymus repens (L.) Gould & 858,2 & III \\
\hline 5 & gorczyca polna - Sinapis arvensis L. & 382,3 & II \\
\hline
\end{tabular}




\begin{tabular}{|c|c|c|c|}
\hline 1 & 2 & 3 & 4 \\
\hline 6 & ostrożeń polny - Cirsium arvense (L.) Scop. & 266 & II \\
\hline 7 & rumian polny - Anthemis arvensis $\mathrm{L}$. & 258,2 & I \\
\hline 8 & rdest szczawiolistny - Polygonum lapathifolium L. spp. pallidum (Witch.) Fr. & 239,7 & II \\
\hline 9 & dymnica pospolita - Fumaria officinalis $\mathrm{L}$. & 237,5 & I \\
\hline 10 & rdest plamisty - Polygonum persicaria $\mathrm{L}$. & 213,5 & II \\
\hline 11 & tobołki polne - Thlaspi arvense L. & 155,5 & II \\
\hline 12 & szarłat szorstki-Amaranthus retroflexus $\mathrm{L}$. & 137,2 & I \\
\hline 13 & rzepak samosiewy - Brassica napus subsp. napus & 110,5 & I \\
\hline 14 & kapusta czarna - Brassica nigra (L.) W.P.J. Koch & 110,5 & I \\
\hline 15 & rdest powojowy - Fallopia convolvulus (L.) Á. Löve & 97,7 & I \\
\hline 16 & włośnica sina - Setaria pumila (Poir.) Roem. \& Schult & 91,7 & I \\
\hline 17 & chaber bławatek - Centaurea cyanus $\mathrm{L}$. & 81,6 & $\mathrm{I}$ \\
\hline 18 & gwiazdnica pospolita - Stellaria media (L.) Vill. & 68,6 & I \\
\hline 19 & iglica pospolita - Erodium cicutarium (L.) L'Hér. & 60,6 & I \\
\hline 20 & wiechlina roczna - Poa annua $\mathrm{L}$. & 58 & I \\
\hline 21 & skrzyp polny - Equisetum arvense L. & 52,7 & I \\
\hline 22 & mlecz polny - Sonchus arvensis L. & 50,5 & I \\
\hline 23 & podbiał pospolity - Tussilago farfara $\mathrm{L}$. & 50 & I \\
\hline 24 & nostrzyk żółty - Melilotus officinalis L. & 42,1 & I \\
\hline 25 & fiołek polny - Viola arvensis Murray & 37,7 & $\mathrm{I}$ \\
\hline 26 & tasznik pospolity - Capsella bursa-pastoris (L.) Medik & 37,2 & $\mathrm{I}$ \\
\hline 27 & rdest ptasi - Polygonum aviculare $\mathrm{L}$. & 34,5 & $\mathrm{I}$ \\
\hline 28 & pokrzywa żegawka - Urtica urens L. & 31,7 & I \\
\hline 29 & sporek polny - Spergula arvensis L. & 29,1 & I \\
\hline 30 & lulek czarny - Hyoscyamus niger L. & 28,9 & I \\
\hline 31 & przetacznik perski - Veronica persica L. & 18,5 & I \\
\hline 32 & przytulia czepna - Galium aparine $\mathrm{L}$. & 16,4 & I \\
\hline 33 & wilczomlecz obrotny - Euphorbia helioscopia L. & 16,1 & I \\
\hline 34 & miotła zbożowa - Apera spica-venti (L.) P. Beauv. & 15,9 & I \\
\hline 35 & kurzyślad polny - Anagallis arvensis $\mathrm{L}$. & 11,1 & I \\
\hline 36 & szczawik zajęczy - Oxalis acetosella $\mathrm{L}$. & 10,7 & $\mathrm{I}$ \\
\hline 37 & powój polny - Convolvulus arvensis $\mathrm{L}$. & 10,6 & I \\
\hline 38 & bodziszek drobny - Geranium pusillum Burm. f. ex L. & 5,7 & I \\
\hline 39 & babka lancetowata - Plantago lanceolata $\mathrm{L}$. & 5,5 & I \\
\hline 40 & przymiotno kanadyjskie - Erigeron canadensis L. & 5,4 & I \\
\hline 41 & czyściec błotny - Stachys palustris L. & 5,4 & I \\
\hline 42 & łoboda ogrodowa - Atriplex hortensis L. & 5,3 & $\mathrm{I}$ \\
\hline 43 & palusznik krwawy - Digitaria sanguinalis (L.) Scop. & 5,3 & I \\
\hline 44 & rdest ziemnowodny - Polygonum amphibia (L.) Gray & 5,3 & I \\
\hline 45 & włośnica zielona - Setaria viridis (L.) P. Beauv. & 5,3 & $\mathrm{I}$ \\
\hline 46 & mniszek lekarski - Taraxacum officinale F.H. Wigg. & 5,3 & $\mathrm{I}$ \\
\hline 47 & maruna bezwonna - Tripleurospermum maritimum (L.) W.D.J. Koch ssp. inodorum (L.) Appleq. & 5,3 & I \\
\hline 48 & wyka czteronasienna - Vicia tetrasperma $($ L.) Schreb. & 5,3 & I \\
\hline
\end{tabular}

Liczba gatunków sporadycznych i rzadkich - Numer of species of sporadic and rare: 49 jasnota różowa - Lamium amplexicaule L., 50 starzec zwyczajny - Senecio vulgaris L., 51 babka zwyczajna - Plantago major L., 52 mietlica pospolita - Agrostis vulgaris L.,

53 farbownik polny - Anchusa arvensis (L.) M. Bieb., 54 owies głuchy - Avena fatua L., 55 jasnota purpurowa - Lamium purpureum L., 56 rzodkiew świrzepa - Raphanus raphanistrum L., 57 szczaw tępolistny - Rumex obtusifolius L., 58 żywokost lekarski Symphytum officinale L., 59 przetacznik polny - Veronica arvensis L., 60 przetacznik bluszczykowaty - Veronica hederifolia L., 61 wyka kosmata - Vicia villosa Roth., 62 fiołek trójbarwny - Viola tricolor L.

W.p.: 0,5-0,1; S: I

S - stałość fitosocjologiczna - phytosociological stability, W.p. - współczynnik pokrycia - cover index 
Tabela 4. Stan zachwaszczenia upraw kukurydzy gatunkami segetalnymi na podstawie 179 zdjęć fitosocjologicznych w makroregionie południowo-zachodnim Polski wykonanych w latach 1973-1982

Table 4. Weed infestation of corn according to phytosociological pictures in southwestern macro-region of Poland performed in $1973-1982$

\begin{tabular}{|c|c|c|c|}
\hline Lp. - No. & Gatunek - Species & W.p. & S \\
\hline 1 & komosa biała - Chenopodium album $\mathrm{L}$. & 2325,9 & $\mathrm{~V}$ \\
\hline 2 & chwastnica jednostronna - Echinochloa crus-galli (L.) P. Beauv. & 1444,9 & IV \\
\hline 3 & przytulia czepna - Galium aparine $\mathrm{L}$. & 917,3 & III \\
\hline 4 & żółtlica drobnokwiatowa - Galinsoga parviflora Cav. & 484,3 & II \\
\hline 5 & gwiazdnica pospolita - Stellaria media (L.) Vill. & 338,8 & II \\
\hline 6 & szarłat szorstki - Amaranthus retroflexus L. & 333,1 & II \\
\hline 7 & tobołki polne - Thlaspi arvense $\mathrm{L}$. & 174,6 & II \\
\hline 8 & gorczyca polna - Sinapis arvensis L. & 145,8 & I \\
\hline 9 & tasznik pospolity - Capsella bursa-pastoris (L.) Medik & 110,6 & I \\
\hline 10 & przetacznik perski - Veronica persica $\mathrm{L}$. & 106,4 & I \\
\hline 11 & jasnota różowa - Lamium amplexicaule $\mathrm{L}$. & 102,1 & I \\
\hline 12 & pokrzywa żegawka - Urtica urens L. & 87,3 & I \\
\hline 13 & wilczomlecz obrotny - Euphorbia helioscopia L. & 86,5 & I \\
\hline 14 & rdest szczawiolistny - Polygonum lapathifolium L. ssp. pallidum (Witch.) Fr. & 84,3 & I \\
\hline 15 & rdest powojowy - Fallopia convolvulus (L.) Á. Löve & 83,3 & I \\
\hline 16 & kapusta czarna - Brassica nigra (L.) W.P.J. Koch & 46,6 & I \\
\hline 17 & miotła zbożowa - Apera spica-venti (L.) P. Beauv. & 46,5 & I \\
\hline 18 & perz właściwy - Elymus repens (L.) Gould & 45,2 & I \\
\hline 19 & blekot pospolity - Aethusa cynapium $\mathrm{L}$. & 32 & I \\
\hline 20 & rzepak samosiewy - Brassica napus ssp. napus & 32 & I \\
\hline 21 & ostrożeń polny - Cirsium arvense (L.) Scop. & 27,8 & I \\
\hline 22 & dymnica pospolita - Fumaria officinalis $\mathrm{L}$. & 24,8 & I \\
\hline 23 & rdest plamisty - Polygonum persicaria $\mathrm{L}$. & 24,1 & I \\
\hline 24 & kurzyślad polny - Anagallis arvensis $\mathrm{L}$. & 23,5 & I \\
\hline 25 & fiołek polny - Viola arvensis Murray & 20,9 & I \\
\hline 26 & rzodkiew świrzepa - Raphanus raphanistrum $\mathrm{L}$. & 18,9 & I \\
\hline 27 & jasnota purpurowa - Lamium purpureum $\mathrm{L}$. & 17,4 & I \\
\hline 28 & rumianek bezpromiennikowy - Chamomilla suaveolens (Pursh) Rydb. & 16 & I \\
\hline 29 & włośnica sina - Setaria pumila (Poir.) Roem. \& Schult & 11,7 & I \\
\hline 30 & maruna bezwonna - Tripleurospermum maritimum (L.) W.D.J. Koch ssp. inodorum (L.) Appleq. & 8,7 & I \\
\hline 31 & rumian polny - Anthemis arvensis $\mathrm{L}$. & 5,9 & I \\
\hline 32 & rumianek pospolity - Chamomilla recutita $($ L.) Rauschert & 5,8 & $\mathrm{I}$ \\
\hline 33 & babka zwyczajna - Plantago major L. & 5,8 & I \\
\hline 34 & rdest ptasi - Polygonum aviculare L. & 3,1 & I \\
\hline 35 & szczawik zajęczy - Oxalis acetosella L. & 2,9 & I \\
\hline 36 & mak polny - Papaver rhoeas L. & 2,3 & $\mathrm{I}$ \\
\hline 37 & wiechlina roczna - Poa annua $\mathrm{L}$. & 2,2 & I \\
\hline
\end{tabular}

Liczba gatunków sporadycznych i rzadkich - Numer of species of sporadic and rare: 38 mlecz polny - Sonchus arvensis L., 39 bniec biały - Melandrium album (Mill.) Garcke, 40 psianka czarna - Solanum nigrum L., 41 owies głuchy - Avena fatua L., 42 powój polny Convolvulus arvensis L., 43 iglica pospolita - Erodium cicutarium (L.) L’Hér., 44 poziewnik szorstki - Galeopsis tetrahit L., 45 groszek bulwiasty - Lathyrus tuberosus L., 46 ślaz zaniedbany - Malva neglecta Wallr., 47 niezapominajka polna - Myosotis arvensis (L.) Hill, 48 ożędka groniasta - Neslia paniculata (L.) Desv., 49 mniszek lekarski - Taraxacum officinale F.H. Wigg. W.p.: 0,4-0,1; S: I

S - stałość fitosocjologiczna - phytosociological stability, W.p. - współczynnik pokrycia - cover index 
Tabela 5. Stan zachwaszczenia upraw kukurydzy gatunkami segetalnymi na podstawie 264 zdjęć fitosocjologicznych w makroregionie południowo-zachodnim Polski wykonanych w latach 1983-1992

Table 5. Weed infestation of corn according to phytosociological pictures in southwestern macro-region of Poland performed in 1983-1992

\begin{tabular}{|c|c|c|c|}
\hline Lp. - No. & Gatunek - Species & W.p. & S \\
\hline 1 & komosa biała - Chenopodium album $\mathrm{L}$. & 2823 & $\mathrm{~V}$ \\
\hline 2 & chwastnica jednostronna - Echinochloa crus-galli (L.) P. Beauv. & 1560 & IV \\
\hline 3 & szarłat szorstki-Amaranthus retroflexus $\mathrm{L}$. & 771,5 & III \\
\hline 4 & kapusta czarna - Brassica nigra (L.) W.P.J. Koch & 503 & II \\
\hline 5 & rzepak samosiewy - Brassica napus ssp. napus & 466,5 & II \\
\hline 6 & tobołki polne - Thlaspi arvense $\mathrm{L}$. & 453,4 & II \\
\hline 7 & rdest plamisty - Polygonum persicaria L. & 375,1 & I \\
\hline 8 & przytulia czepna - Galium aparine L. & 371,1 & I \\
\hline 9 & perz właściwy - Elymus repens (L.) Gould & 268,9 & I \\
\hline 10 & gorczyca polna - Sinapis arvensis L. & 246,5 & I \\
\hline 11 & rdest powojowy - Fallopia convolvulus (L.) Á. Löve & 135,5 & I \\
\hline 12 & jasnota purpurowa - Lamium purpureum $\mathrm{L}$. & 107,3 & I \\
\hline 13 & rumian polny - Anthemis arvensis L. & 102,2 & I \\
\hline 14 & psianka czarna - Solanum nigrum L. emend. Mill. & 100,7 & I \\
\hline 15 & żółtlica drobnokwiatowa - Galinsoga parviflora Cav. & 98,8 & I \\
\hline 16 & fiołek polny - Viola arvensis Murray & 71,3 & I \\
\hline 17 & wilczomlecz obrotny - Euphorbia helioscopia L. & 50,7 & I \\
\hline 18 & ostrożeń polny - Cirsium arvense (L.) Scop. & 50,2 & I \\
\hline 19 & kurzyślad polny - Anagallis arvensis $\mathrm{L}$. & 42,6 & I \\
\hline 20 & gwiazdnica pospolita - Stellaria media (L.) Vill. & 40,4 & I \\
\hline 21 & rdest ptasi - Polygonum aviculare L. & 38,8 & I \\
\hline 22 & przetacznik perski - Veronica persica L. & 28,7 & I \\
\hline 23 & dymnica pospolita - Fumaria officinalis L. & 25,5 & I \\
\hline 24 & tasznik pospolity - Capsella bursa-pastoris (L.) Medik & 23,1 & I \\
\hline 25 & powój polny - Convolvulus arvensis $\mathrm{L}$. & 17,3 & I \\
\hline 26 & jasnota różowa - Lamium amplexicaule $\mathrm{L}$. & 15,6 & I \\
\hline 27 & sporek polny - Spergula arvensis $\mathrm{L}$. & 11,6 & I \\
\hline 28 & wiechlina roczna - Poa annua $\mathrm{L}$. & 7,8 & I \\
\hline 29 & skrzyp polny - Equisetum arvense $\mathrm{L}$. & 5,9 & I \\
\hline 30 & przetacznik polny - Veronica arvensis L. & 5,9 & I \\
\hline 31 & rdest szczawiolistny - Polygonum lapathifolium L. ssp. pallidum (Witch.) Fr. & 5,7 & I \\
\hline 32 & włośnica sina - Setaria pumila (Poir.) Roem. \& Schult & 5,7 & I \\
\hline 33 & lulek czarny - Hyoscyamus niger L. & 3,9 & I \\
\hline 34 & bniec biały - Melandrium album (Mill.) Garcke & 3,9 & I \\
\hline 35 & maruna bezwonna - Tripleurospermum maritimum (L.) W.D.J. Koch ssp. inodorum (L.) Appleq. & 3,8 & I \\
\hline 36 & bylica pospolita - Artemisia vulgaris $\mathrm{L}$. & 2,1 & I \\
\hline 37 & blekot pospolity - Aethusa cynapium $\mathrm{L}$. & 2,0 & I \\
\hline 38 & miotła zbożowa - Apera spica-venti (L.) P. Beauv. & 1,9 & I \\
\hline 39 & poziewnik szorstki - Galeopsis tetrahit L. & 1,9 & I \\
\hline 40 & mak polny - Papaver rhoeas $\mathrm{L}$. & 1,6 & I \\
\hline 41 & iglica pospolita - Erodium cicutarium (L.) L'Hér. & 1,3 & I \\
\hline
\end{tabular}

Liczba gatunków sporadycznych i rzadkich - Numer of species of sporadic and rare: 42 wyka wąskolistna - Vicia angustifolia L., 43 owies głuchy - Avena fatua L., 44 szczawik zajęczy - Oxalis acetosella L., 45 mlecz polny - Sonchus arvensis L.

W.p.: 0,6-0,1; S: I

S - stałość fitosocjologiczna - phytosociological stability, W.p. - współczynnik pokrycia - cover index 
Tabela 6. Stan zachwaszczenia upraw kukurydzy gatunkami segetalnymi na podstawie 470 zdjęć fitosocjologicznych w makroregionie południowo-zachodnim Polski wykonanych w latach 1993-2002

Table 6. Weed infestation of corn according to phytosociological pictures in southwestern macro-region of Poland performed in 1993-2002

\begin{tabular}{|c|c|c|c|}
\hline Lp. - No. & Gatunek - Species & W.p. & $\mathrm{S}$ \\
\hline 1 & 2 & 3 & 4 \\
\hline 1 & komosa biała - Chenopodium album $\mathrm{L}$. & 1523,5 & IV \\
\hline 2 & chwastnica jednostronna - Echinochloa crus-galli (L.) P. Beauv. & 1783,7 & $\mathrm{~V}$ \\
\hline 3 & szarlat szorstki - Amaranthus retroflexus $\mathrm{L}$. & 350,1 & II \\
\hline 4 & fiołek polny - Viola arvensis Murray & 332,1 & $\mathrm{~V}$ \\
\hline 5 & perz właściwy - Elymus repens (L.) Gould & 297,2 & I \\
\hline 6 & przytulia czepna - Galium aparine $\mathrm{L}$. & 269,4 & III \\
\hline 7 & tobołki polne - Thlaspi arvense $\mathrm{L}$. & 232,6 & III \\
\hline 8 & rdest powojowy - Fallopia convolvulus (L.) Á. Löve & 199,1 & III \\
\hline 9 & rumian polny - Anthemis arvensis $\mathrm{L}$. & 196 & III \\
\hline 10 & psianka czarna - Solanum nigrum L. emend. Mill. & 181,3 & III \\
\hline 11 & przetacznik perski - Veronica persica L. & 172,3 & III \\
\hline 12 & gwiazdnica pospolita - Stellaria media (L.) Vill. & 163,7 & III \\
\hline 13 & włośnica zielona - Setaria viridis (L.) P. Beauv. & 163,3 & II \\
\hline 14 & jasnota purpurowa - Lamium purpureum L. & 162,9 & III \\
\hline 15 & bodziszek drobny - Geranium pusillum Burm. f. ex L. & 130,4 & II \\
\hline 16 & rdest ptasi - Polygonum aviculare $\mathrm{L}$. & 115,3 & II \\
\hline 17 & kapusta czarna - Brassica nigra (L.) W.P.J. Koch & 114,8 & II \\
\hline 18 & przetacznik bluszczykowy - Veronica hederifolia L. & 99,6 & II \\
\hline 19 & rdest plamisty - Polygonum persicaria $\mathrm{L}$. & 85,9 & II \\
\hline 20 & maruna bezwonna - Tripleurospermum maritimum (L.) W.D.J. Koch ssp. inodorum (L.) Appleq. & 85,2 & I \\
\hline 21 & tasznik pospolity - Capsella bursa-pastoris (L.) Medik & 82 & II \\
\hline 22 & rumian polny - Anthemis arvensis $\mathrm{L}$. & 69,8 & II \\
\hline 23 & wilczomlecz obrotny - Euphorbia helioscopia L. & 57,7 & II \\
\hline 24 & mak polny - Papaver rhoeas $\mathrm{L}$. & 49,5 & I \\
\hline 25 & gorczyca polna - Sinapis arvensis L. & 49,1 & I \\
\hline 26 & chaber bławatek - Centaurea cyanus L. & 46,8 & I \\
\hline 27 & dymnica pospolita - Fumaria officinalis L. & 44,3 & I \\
\hline 28 & pszenica zwyczajna samosiewy - Triticum aestivum L. & 33,5 & I \\
\hline 29 & bylica pospolita - Artemisia vulgaris $\mathrm{L}$. & 32,9 & I \\
\hline 30 & wilczomlecz obrotny - Euphorbia helioscopia L. & 29,4 & I \\
\hline 31 & żółtlica drobnokwiatowa - Galinsoga parviflora Cav. & 29 & I \\
\hline 32 & ostrożeń polny - Cirsium arvense (L.) Scop. & 27,4 & I \\
\hline 33 & palusznik krwawy - Digitaria sanguinalis (L.) Scop. & 25,9 & I \\
\hline 34 & lulek czarny - Hyoscyamus niger L. & 24,8 & I \\
\hline 35 & jasnota różowa - Lamium amplexicaule $\mathrm{L}$. & 21,9 & II \\
\hline 36 & rzepak samosiewy - Brassica napus sp. napus & 19,7 & I \\
\hline 37 & stulisz lekarski - Sisymbrium officinale (L.) Scop. & 10,1 & I \\
\hline 38 & iglica pospolita - Erodium cicutarium (L.) L’Hér. & 9,8 & I \\
\hline 39 & bniec biały - Melandrium album (Mill.) Garcke & 6,5 & I \\
\hline 40 & powój polny - Convolvulus arvensis $\mathrm{L}$. & 5,9 & I \\
\hline 41 & niezapominajka polna - Myosotis arvensis (L.) Hill & 5,6 & I \\
\hline 42 & kurzyślad polny - Anagallis arvensis $\mathrm{L}$. & 3,3 & I \\
\hline 43 & rumianek pospolity - Chamomilla recutita $($ L.) Rauschert & 2,1 & I \\
\hline
\end{tabular}




\begin{tabular}{c|l|c|c}
\hline 1 & \multicolumn{1}{|c|}{2} & 3 & 4 \\
\hline 44 & farbownik polny - Anchusa arvensis (L.) M. Bieb. & 1,4 & I \\
\hline 45 & mlecz polny - Sonchus arvensis L. & 1,3 & I \\
\hline
\end{tabular}

Liczba gatunków sporadycznych i rzadkich - Numer of species of sporadic and rare: 46 łopian mniejszy - Arctium minus (Hill) Bernh., 47 wyka kosmata - Vicia villosa Roth, 48 sporek polny - Spergula arvensis L., 49 rdest szczawiolistny -Polygonum lapathifolium L. ssp. pallidum (With.) Fr., 50 krwawnik pospolity - Achillea millefolium L., 51 łoboda ogrodowa - Atriplex hortensis L., 52 stulicha psia - Descurainia sophia (L.) Webb ex Prantl, 53 przymiotno kanadyjskie - Erigeron canadensis L.

W.p.: $0,5-0,1 ; \mathrm{S}: \mathrm{I}$

S - stałość fitosocjologiczna - phytosociological stability, W.p. - współczynnik pokrycia - cover index

Tabela 7. Stan zachwaszczenia upraw kukurydzy gatunkami segetalnymi na podstawie 444 zdjęć fitosocjologicznych w makroregionie południowo-zachodnim Polski wykonanych w latach 2003-2013

Table 7. Weed infestation of corn according to phytosociological pictures in southwestern macro-region of Poland performed in 2003-2013

\begin{tabular}{|c|c|c|c|}
\hline Lp. - No. & Gatunek - Species & W.p. & $\mathrm{S}$ \\
\hline 1 & 2 & 3 & 4 \\
\hline 1 & komosa biała - Chenopodium album $\mathrm{L}$. & 1512,1 & $\mathrm{~V}$ \\
\hline 2 & chwastnica jednostronna - Echinochloa crus-galli (L.) P. Beauv. & 1704,2 & $\mathrm{~V}$ \\
\hline 3 & włośnica zielona - Setaria viridis (L.) P. Beauv. & 602 & III \\
\hline 4 & fiołek polny - Viola arvensis Murray & 280,6 & III \\
\hline 5 & włośnica sina - Setaria pumila (Poir.) Roem. \& Schult & 268,3 & $\mathrm{I}$ \\
\hline 6 & tobołki polne - Thlaspi arvense $\mathrm{L}$. & 163,7 & II \\
\hline 7 & szarłat szorstki - Amaranthus retroflexus $\mathrm{L}$. & 153,5 & II \\
\hline 8 & rzepak samosiewy - Brassica napus ssp. napus & 151 & $\mathrm{I}$ \\
\hline 9 & psianka czarna - Solanum nigrum L. emend. Mill. & 150,1 & II \\
\hline 10 & przetacznik perski - Veronica persica $\mathrm{L}$. & 146,4 & II \\
\hline 11 & jasnota purpurowa - Lamium purpureum $\mathrm{L}$. & 132,5 & II \\
\hline 12 & rumian polny - Anthemis arvensis $\mathrm{L}$. & 129,9 & III \\
\hline 13 & przytulia czepna - Galium aparine $\mathrm{L}$. & 127,9 & II \\
\hline 14 & rdest powojowy - Fallopia convolvulus (L.) Á. Löve & 113,9 & II \\
\hline 15 & gwiazdnica pospolita - Stellaria media (L.) Vill. & 97,4 & III \\
\hline 16 & bodziszek drobny - Geranium pusillum Burm. f. ex L. & 97,2 & II \\
\hline 17 & rdest plamisty - Polygonum persicaria $\mathrm{L}$. & 77,8 & II \\
\hline 18 & rdest ptasi - Polygonum aviculare $\mathrm{L}$. & 73 & $\mathrm{I}$ \\
\hline 19 & przetacznik bluszczykowy - Veronica hederifolia L. & 70,4 & I \\
\hline 20 & tasznik pospolity - Capsella bursa-pastoris (L.) Medik & 68,4 & II \\
\hline 21 & perz właściwy - Elymus repens (L.) Gould & 66,4 & I \\
\hline 22 & maruna bezwonna - Tripleurospermum maritimum (L.) W.D.J. Koch ssp. inodorum (L.) Appleq. & 60 & I \\
\hline 23 & blekot pospolity - Aethusa cynapium $\mathrm{L}$. & 53,5 & I \\
\hline 24 & bylica pospolita - Artemisia vulgaris $\mathrm{L}$. & 43,1 & I \\
\hline 25 & kapusta czarna - Brassica nigra (L.) W.P.J. Koch & 39,6 & I \\
\hline 26 & mak polny - Papaver rhoeas $\mathrm{L}$. & 35,3 & I \\
\hline 27 & wilczomlecz obrotny - Euphorbia helioscopia L. & 34,3 & I \\
\hline 28 & chaber bławatek - Centaurea cyanus $\mathrm{L}$. & 33,7 & I \\
\hline 29 & żółtlica drobnokwiatowa - Galinsoga parviflora Cav. & 32,8 & I \\
\hline 30 & dymnica pospolita - Fumaria officinalis L. & 29,3 & I \\
\hline 31 & ostrożeń polny - Cirsium arvense (L.) Scop. & 27,4 & I \\
\hline 32 & gorczyca polna - Sinapis arvensis L. & 25,9 & I \\
\hline 33 & skrzyp polny - Equisetum arvense $\mathrm{L}$. & 22,4 & I \\
\hline 34 & palusznik krwawy - Digitaria sanguinalis (L.) Scop. & 18,7 & I \\
\hline
\end{tabular}




\begin{tabular}{|c|c|c|c|}
\hline 1 & 2 & 3 & 4 \\
\hline 35 & lulek czarny - Hyoscyamus niger L. & 15,9 & I \\
\hline 36 & jasnota różowa - Lamium amplexicaule $\mathrm{L}$. & 13,4 & I \\
\hline 37 & szczaw zwyczajny - Rumex acetosa $\mathrm{L}$. & 12,9 & I \\
\hline 38 & bniec biały - Melandrium album (Mill.) Garcke & 10,9 & I \\
\hline 39 & farbownik polny - Anchusa arvensis (L.) M. Bieb. & 7,3 & I \\
\hline 40 & iglica pospolita - Erodium cicutarium (L.) L’Hér. & 5,6 & I \\
\hline 41 & mlecz polny - Sonchus arvensis $\mathrm{L}$. & 4,9 & I \\
\hline 42 & komosa wielonasienna - Chenopodium polyspermum L. & 4 & I \\
\hline 43 & kurzyślad polny - Anagallis arvensis $\mathrm{L}$. & 3,8 & I \\
\hline 44 & rumianek pospolity - Chamomilla recutita (L.) Rauschert & 3 & I \\
\hline 45 & komosa wielkolistna - Chenopodium hybridum $\mathrm{L}$. & 2,8 & I \\
\hline 46 & stulicha psia - Descurainia sophia (L.) Webb ex Prantl & 2,2 & I \\
\hline
\end{tabular}

Liczba gatunków sporadycznych i rzadkich - Number of species of sporadic and rare: 47 zaślaz pospolity - Abutilon theophrasti Medik, 48 wyka wąskolistna - Vicia angustifolia L., 49 niezapominajka polna - Myosotis arvensis (L.) Hill, 50 rdest szczawiolistny Polygonum lapathifolium L. ssp. pallidum (Witch.) Fr., 51 przymiotno kanadyjskie - Erigeron canadensis L.

W.p.: $0,5-0,1 ;$ S: I

S - stałość fitosocjologiczna - phytosociological stability, W.p. - współczynnik pokrycia - cover index

W omawianym okresie w grupie chwastów sporadycznie spotykanych w uprawie kukurydzy znajdowało się 9 gatunków.

Badania prowadzone w latach 2003-2013 przypadły na okres, w którym na stan zachwaszczenia duży wpływ miały: wzrost temperatury $\mathrm{w}$ porównaniu ze średnimi wieloletnimi, częstsze występowanie łagodnych, bezśnieżnych zim oraz szybsza wegetacja.

$\mathrm{Z}$ obserwacji stanu zachwaszczenia na plantacjach kukurydzy wynika, że wczesne przedwiośnie pobudzało rozwój większej liczby gatunków chwastów i korzystniej wpływało na ich kondycję. Niektóre z nich już na początku wegetacji kukurydzy były bardziej rozwinięte, często z formami, które przetrwały bezśnieżną zimę. Na wszystkich stanowiskach glebowych nadal dominowały chwastnica jednostronna i komosa biała, jednak $\mathrm{z}$ niższymi współczynnikami pokrycia w porównaniu do poprzednich dziesięcioleci, w stosunku do których notowano większy udział gatunków ciepłolubnych, późnowschodzących, jak: włośnica zielona [Setaria viridis (L.) P. Beauv.], psianka czarna (Solanum nigrum L.), blekot pospolity (Aethusa cynapium L.), czy lulek czarny (Hyoscyamus niger L.) oraz gatunków towarzyszących uprawom zbóż takich, jak przytulia czepna (Galium aparine L.) i palusznik krwawy [Digitaria sanguuinalis (L.) Scop.]. W porównaniu do minionej dekady spadła liczba gatunków ze stałością fitosocjologiczną $\mathrm{w}$ stopniach od V do II z 22 do 16 taksonów oraz nadal następowało ubożenie różnorodności w grupie pozostałych gatunków listy florystycznej zarówno jednorocznych, jak i wieloletnich. Coraz częściej zaznaczają swoją obecność gatunki ekspansywne ciepłolubne, jak zaślaz pospolity (Abutilon theophrasti Medik), czy przymiotno kanadyjskie (Erigeron canadensis L.). Dalsze uproszczenia uprawowe, zwłaszcza monokultury oraz przywracanie gruntów odłogowanych do rolniczego użytkowania, były powodem wzrastającego zagrożenia bylicą pospolitą oraz istotnych przekształceń w zbiorowiskach chwastów towarzyszących kukurydzy.
Ponad 53\% obszaru województwa dolnośląskiego stanowią gleby należące do kompleksów pszennych bardzo dobrych i dobrych z dużym udziałem czarnych ziem, czarnoziemów i gleb brunatnych, a około 33\% gleby należące do kompleksów żytniego bardzo dobrego i dobrego, wśród nich gorsze stanowiska gleb brunatnych i gleby płowe nadające się jednak pod uprawę kukurydzy (Rocznik Statystyczny 2009).

Źródłem zachwaszczenia upraw rolniczych jest glebowy bank nasion, a na ich procesy życiowe w danym siedlisku w głównej mierze oddziałują czynniki agroekologiczne (Grundy i Jones 2002). Czynniki te warunkują: wytwarzanie, rozsiewanie i rozprzestrzenianie nasion, a z drugiej strony wpływają na ich przeżywalność w glebie, dzięki czemu mogą stawać się silnymi konkurentami i stwarzać zagrożenie agrocenoz (Falińska i wsp. 1994; Buhler i wsp. 2001; Davies i Forcella 2007; Riemens i wsp. 2007). Wprowadzanie uproszczeń uprawowych, jak i monokultury kukurydzy może istotnie wpływać na stan zachwaszczenia i dezorganizować dotychczasowy względny stan równowagi $\mathrm{w}$ zbiorowiskach wynikający $\mathrm{z}$ uprawy opartej na orce i płodozmianie (Stupnicka-Rodzynkiewicz i Lepiarczyk 2004; Jędruszczak i wsp. 2007; Sekutowski i Smagacz 2011).

W opracowaniach oceniających bioróżnorodność zbiorowisk chwastów stosuje się najczęściej metodę BraunBlanqueta lub wykorzystuje wskaźniki różnorodności Shannona i dominacji Simsona lub posługuje się określonymi modelami statystycznymi (Goodman 1978; Wesołowski 1984; Feledyn-Szewczyk i Duer 2004). Z tych doniesień literaturowych wiadomo, że niezależnie od przyjętej metody największą liczebnością w zbiorowisku chwastów towarzyszacych kukurydzy zawsze charakteryzowały się chwastnica jednostronna i komosa biała bez względu na stanowisko glebowe i wielkość gospodarstwa. Istotnie większą liczbę włośnicy zielonej, szarłatu szorstkiego i psianki czarnej wykazano na czarnych ziemiach $\mathrm{w}$ porównaniu $\mathrm{z}$ pozostałymi stanowiskami. $\mathrm{Na}$ glebach 
brunatnych w dużym nasileniu wystąpiły chwastnica jednostronna, komosa biała oraz przetaczniki. Natomiast gleby płowe charakteryzowały się najwyższą liczebnością na jednostce powierzchni takich gatunków, jak: chwastnica jednostronna, komosa biała, fiołek polny, rumian polny i perz właściwy (Gołębiowska 2011).

Zespołowe badania prowadzone w latach 1972-1991 pozwoliły ustalić stan zachwaszczenia na plantacjach kukurydzy w rejonie województwa wrocławskiego. W tym okresie największym zagrożeniem okazały się: chwastnica jednostronna, komosa biała, perz właściwy i gwiazdnica pospolita. Natomiast rdest powojowaty i plamisty oraz włośnice pojawiały się rzadziej i w mniejszym nasileniu, najczęściej na małopowierzchniowych plantacjach (Rola i wsp. 1987a, b, 1992). W badaniach własnych w analogicznym okresie w uprawie kukurydzy występował podobny stan zachwaszczenia również $\mathrm{z}$ dominacją komosy białej i chwastnicy jednostronnej, jednak z większym nasileniem występowania szarłatu szorstkiego na żyźniejszych glebach oraz przytuli czepnej w efekcie wysycania płodozmianów zbożami. Lokalnie na słabszych kompleksach glebowych licznie pojawiała się żółtlica drobnokwiatowa.

Istotny wpływ na kształtowanie stanu i stopnia zachwaszczenia wywiera technologia uprawy kukurydzy, a zwłaszcza związana $\mathrm{z}$ nią gospodarka płodozmianowa. $\mathrm{Na}$ przestrzeni lat uległa ona znacznemu uproszczeniu w związku z rozszerzeniem areału uprawy zbóż. Zmiany technologii uprawy kukurydzy najczęściej wymuszały czynniki organizacyjno-ekonomiczne takie, jak:

- uproszczenia w zakresie zmianowania roślin i uprawy roli,

- wzrost nawożenia mineralnego, a zwłaszcza azotowego,

- pojawienie się odmian roślin dobrze przystosowanych do zbioru mechanicznego, ale mniej konkurencyjnych $\mathrm{z}$ chwastami,

- uzupełnienie metod agrotechnicznej walki z chwastami metodami chemicznymi, które w największym stopniu decydowały o stanie i stopniu zachwaszczenia pól (Adamczewski i wsp. 1994; Rola i Rola 2000).

Również w warunkach intensywnego gospodarowania istotnym stało się odchodzenie od tradycyjnego płodozmianu, duże wysycenie go tylko zbożami, bądź nawet wieloletnie uprawianie kukurydzy w monokulturze, co w dużej mierze wpływało na zmiany w jej zachwaszczeniu. Natomiast warunki siedliskowe, jak podaje Domaradzki i Rola (2002), zaczęły odgrywać drugorzędną rolę $\mathrm{w}$ różnicowaniu zbiorowisk chwastów. Wszelkie uproszczenia w technologii uprawy kukurydzy według Blecharczyka i wsp. (2004) mogą przyczyniać się w pierwszych latach stosowania do wzrostu zachwaszczenia, zwłaszcza gatunkami jednoliściennymi.

W badaniach własnych z lat 1993-2002 wprowadzane uproszczenia uprawowe wpływały na: wzrost zachwaszczenia, dominację chwastnicy jednostronnej przed komosą białą, pojawienie się wieloletniej bylicy pospolitej i jej wzrost pokrycia w zasiewach zwłaszcza na stanowiskach gleb płowych. Ten stan zachwaszczenia utrzymywał się $\mathrm{w}$ latach 2004-2013, dodatkowo $\mathrm{z}$ większym nasileniem gatunków ciepłolubnych zwłaszcza włoś-nic sinej i zielonej.
W ostatnich latach na stan zachwaszczenia duży wpływ wywierają skutki wzrostu temperatury. Przeprowadzony w latach 1971-2000 monitoring warunków termicznych i opadów dla Polski wykazał, że wartość średniej rocznej temperatury powietrza dla całego kraju wynosiła $8,0^{\circ} \mathrm{C}$, czyli była o $0,3^{\circ} \mathrm{C}$ wyższa od notowanej w latach $1961-$ 1990. Natomiast sumy opadów atmosferycznych uśrednione dla obszaru Polski w porównywalnych okresach nie uległy większym zmianom (Bogdan 2002; Górski i Zaliwski 2002; Zawora i wsp. 2005). Na skutek abiotycznego oddziaływania tych czynników doszło do zmian pojawów fenologicznych - wschodów, kwitnienia, owocowania i dojrzewania chwastów, co zwiększyło ich ekspansywność w zbiorowisku i naraziło kukurydzę na silniejszą konkurencję (Kwiatkowska-Anioł 1998; Stuczyński i wsp. 2000; Kozyra 2004).

Zmiany zachwaszczenia w uprawie kukurydzy w latach 1983-1992 przypadły na okres nasilonego stosowania tanich i dających długo utrzymujący się efekt czystego pola herbicydów triazynowych oraz większej koncentracji uprawy kukurydzy w gospodarstwach wielkoobszarowych (Rola i wsp. 1992). Wysycanie płodozmianów rzepakiem ozimym i zbożami skutkowało obecnością ich samosiewów w zasiewach. Dalsze uproszczenia uprawowe, zwłaszcza monokultury oraz przywracanie gruntów odłogowanych do rolniczego użytkowania były powodem wzrastającego zagrożenia bylicą pospolitą oraz istotnych przekształceń w zbiorowiskach chwastów towarzyszących kukurydzy (Rola i Rola 2000).

Najbardziej niekorzystnym okresem oddziałującym na stan zachwaszczenia kukurydzy w rejonie południowozachodnim były lata 1993-2002. Na ten stan złożyły się przekształcenia własnościowe $\mathrm{w}$ rolnictwie wielkoobszarowym, gwałtowny spadek powierzchni uprawy kukurydzy na kiszonkę i związana $\mathrm{z}$ tym zmiana kierunku użytkowania na ziarnowy, a pod koniec tego okresu wprowadzanie uproszczeń uprawowych (tab. 1). Liczne wyniki obserwacji potwierdzały prawidłowość większego bogactwa gatunkowego chwastów charakteryzujących się większą stabilnością i występujących w niewielkich liczebnościach $\mathrm{w}$ zbiorowisku na stanowiskach $\mathrm{z}$ zastosowaniem płodozmianu $\mathrm{W}$ porównaniu $\mathrm{z}$ monokulturą, gdzie obserwowano nasiloną obecność tylko kilku gatunków chwastów (Kuś 2003; Blecharczyk i wsp. 2004).

W latach 2003-2013, na podstawie obserwacji stanu zachwaszczenia na plantacjach kukurydzy, wczesne przedwiośnia pobudzały rozwój większej liczby gatunków chwastów i korzystniej wpływały na ich kondycję. Niektóre $\mathrm{z}$ nich już na początku wegetacji kukurydzy były bardziej rozwinięte, często $\mathrm{z}$ formami, które przetrwały bezśnieżną zimę, jak: przetaczniki, bodziszki czy rumianowate (Gołębiowska 2011). W stosunku do poprzednich obserwacji notowano większy udział gatunków ciepłolubnych, późnowschodzących, jak: włośnica zielona ( $S$. viridis), psianka czarna (S. nigrum), blekot pospolity (A. cynapium), czy lulek czarny $(H$. niger) oraz, jak donoszą Domaradzki i wsp. (2008), wzrasta udział w zbiorowiskach gatunków ekspansywnych, jak (Abutilon theophrasti Medik). 


\section{Wnioski / Conclusions}

1. W rejonie południowo-zachodnim w latach 1963-1972 na liście flory segetalnej w uprawie kukurydzy dominowały: komosa biała, chwastnica jednostronna, perz właściwy, ostrożeń polny, a na glebach płowych: gorczyca polna, żółtlica drobnokwiatowa oraz rdesty, na co głównie wpływało zmianowanie: zboża, strączkowe, okopowe oraz wieloletnia uprawa kukurydzy w użytkowaniu kiszonkowym.

2. Podobny stan zachwaszczenia występował w latach 1973-1982, jednak z większą dominacją komosy białej i chwastnicy jednostronnej, wzrostem nasilenia szarłatu szorstkiego oraz mniejszą liczebnością gatunków wieloletnich, na co głównie wpływała intensyfikacja produkcji i większe wykorzystywanie herbicydów w regulacji zachwaszczenia.

3. W latach 1983-1992 na liście flory segetalnej stwierdzono większą bioróżnorodność zwłaszcza w grupie gatunków dwuliściennych jednorocznych, wyższe współczynniki pokrycia dla gatunków dominujących w porównaniu z poprzednimi okresami, na co głównie wpływały: przekształcenia własnościowe w rolnictwie, spadek produkcji oraz zmiana kierunku użytkowania kukurydzy.

4. W latach 1993-2002 na stan zachwaszczenia upraw kukurydzy wpłynęło: stosowanie uproszczeń uprawowych, odejście od prawidłowego płodozmianu, stosowanie monokultury oraz przywracanie odłogów do rolniczego użytkowania kukurydzy. W tej sytuacji notowano większe nasilenie bylicy pospolitej, przymiotna kanadyjskiego i poziewnika szortskiego.

5. Ten stan zachwaszczenia utrzymywał w latach 20032013, jednak z większym nasileniem gatunków ciepłolubnych, zwłaszcza: włośnic sinej i zielonej, psianki czarnej i blekotu pospolitego. Odnotowano również pojawienie się gatunków ekspansywnych, a wśrod nich zaślazu pospolitego (A. theophrasti Medik).

\section{Literatura / References}

Adamczewski K., Praczyk T., Stachecki S. 1994. Wpływ opadów atmosferycznych i temperatury powietrza na występowanie niektórych gatunków chwastów oraz ich konkurencyjność w stosunku do rośliny uprawnej. s. 109-116. Materiały XVII Krajowej Konferencji Naukowej „Przyczyny i źródła zachwaszczenia pól uprawnych”. Olsztyn - Bęsia, 28-29.04.1994. Wyd. ART, Olsztyn, 146 ss.

Banaszak J., Wiśniewski H. 2003. Podstawy ekologii. Wyd. Adam Marszałek, Toruń: 232-246.

Blecharczyk A., Małecka I., Skrzypczak G. 2004. Wpływ uproszczonej uprawy roli na plonowanie i zachwaszczenie kukurydzy oraz na właściwości gleby. Acta Scientiarum Polonorum, Agricultura 3 (1): 157-163.

Bochenek A., Hołdyński Cz. 1996. Ekofizjologiczne uwarunkowania żywotności i wigoru diaspor Echinochloa crus - galli (L) Beauv. w różnych agrocenozach. s. 213-219. Materiały Ogólnopolskiej Konferencji. Kraków, 23-25.11.1995. Wyd. Zakładu Fizjologii Roślin PAN, Kraków, 587 s.

Bogdan I. 2002. The summer rainfall impact to the weediest degree in maize crops. Agricultura-Revistă de ştiintă şi practică agrocolă $11(3 / 4): 18-23$.

Buhler D.D., Kohler K.A., Thompson R.L. 2001. Weed seed bank dynamics during a five-year crop rotation. Weed Technology 15: $170-176$.

Davies A., Forcella F. 2007. Effects of interactions between germination environment, seed provenance and soil disturbance on emergence of Chenopodium album. p. 182-183. Proceedings of 14 EWRS Symposium. Hamar, 18-21.06.2007, 338 pp.

Domaradzki K., Rola H. 2002. Wpływ długotrwałej uprawy roślin zbożowych na dynamikę zachwaszczenia pola. [Effect of long-term cultivation of cereals on the dynamics of weed infestation of fields]. Progress in Plant Protection/Postępy w Ochronie Roślin 42 (1): $228-233$.

Domaradzki K., Snopczyński T., Jezierska-Domaradzka A. 2008. Zaślaz pospolity (Abutilon theophrasti Medik.), nowy groźny chwast upraw polowych - charakterystyka, występowanie i możliwości zwalczania. [Abutilon theophrasti Medik., new dangerous weed characterization, apperance and control possibilities]. Progress in Plant Protection/Postępy w Ochronie Roślin 48 (2): $567-574$.

Falińska K., Jankowska-Błaszczuk M., Szydłowska J. 1994. Bank nasion w glebie a dynamika roślinności. Wiadomości Botaniczne $38(1 / 2): 35-46$.

Feledyn-Szewczyk B., Duer I. 2004. Oddziaływanie systemu produkcji na glebowy bank nasion. Pamiętnik Puławski 138: 19-33.

Gołębiowska H. 2007. Bioróżnorodność zachwaszczenia w kukurydzy oraz chemiczne sposoby jego zwalczania. [Biodiversity of weed communities in maize and chemical systems of weed control]. Progress in Plant Protection/Postępy w Ochronie Roślin 47 (3): 96-107.

Gołębiowska H. 2011. Dynamika występowania flory segetalnej w uprawie kukurydzy na Dolnym Śląsku w latach 1972-2008 i obecne możliwości jej regulacji. Wyd. IUNG - PIB, Puławy. Monografie i rozprawy naukowe 30, p. 113.

Goodman L.A. 1978. Analysing qualitative/categorical Data: log-linear models and latent structure analysis (Jay Magidson) Cambridge: 471-473.

Górski T., Zaliwski A. 2002. Model agroklimatu Polski. Pamiętnik Puławski 130 (1): 251-260.

Grundy A.C., Jones N.E. 2002. What is the weed seed bank. p. 39-62. In: "Weed Management Handbook" (E.L. Naylor, ed.). Blackwell Science Ltd., 423 pp.

Jędruszczak M., Budzyńska B., Gocół M. 2007. Zasobność glebowego banku nasion chwastów w zależności od sposobu regulacji zachwaszczenia. Annales Universitatis Mariae Curie-Skłodowska 62 (2): 217-225.

Kozyra J. 2004. Climatic conditions for millet cultivation in Poland. WMO - CagM Report, Geneva 94: 34-35.

Kuś J. 2003. Plonowanie wybranych gatunków roślin w różnych systemach produkcji. Zeszyty Naukowe Akademii Rolniczej w Krakowie 89: 7-17.

Kuźniewski E. 1988. Występowanie wybranych gatunków chwastów w uprawach rolniczych (1976-1989). Makroregion południowo-zachodni. Wyd. IUNG, Puławy R (220/2): 4-7. 
Kwiatkowska-Anioł J. 1998. Ginące i rzadkie gatunki segetalne na Wale Trzebnickim. Acta Universitatis Lodziensia Folia Botanica 13: $169-176$.

Latowski K., Jackowiak B. 2011. Rozmieszczenie, ekologia i biologia chwastów segetalnych. Bibliografia polskich prac za lata 2006-2010. Prace Zakładu Taksonomii Roślin Uniwersytetu Adama Mickiewicza w Poznaniu 18: 1-130.

Mirek Z., Piękoś-Mirkowa H., Zając A., Zając M. 1995. Vascular plants of Poland. A checklist. Polish Botanical Studies, Guidebook Series 15: 2042-2050.

Pawłowski B. 1972. Skład i budowa zbiorowisk roślinnych oraz metody ich badania. s. 266-267. W: „Szata roślinna Polski” (W. Szafer, K. Zarzycki, red.). PWN, Warszawa, t. 1.

Riemens M.M., Groeneveld R.M., Lotz L.A.P., Kropff M.J. 2007. Effect of three management strategies on the seedbank, emergence and the need for hand weeding in an organic arable cropping system. Weed Research 47 (5): 442-451.

Rocznik Statystyczny 2009. GUS, Warszawa, 483 ss.

Rola J., Rola H. 1987a. Dynamika chwastów segetalnych na polach uprawnych. s. 131-148. Materiały Sympozium „Dynamika zachwaszczenia pól uprawnych". IUNG Puławy. Wrocław, 25-26.06.1987, 224 ss.

Rola J., Rola H. 1987b. Dynamika chwastów segetalnych na polach uprawnych. s. 124-143. Materiały Sympozium „Dynamika zachwaszczenia pól uprawnych". IUNG Puławy. Wrocław, 25-26.06.1987, 224 ss.

Rola J., Rola H. 2000. Problem odłogów na gruntach porolnych i perspektywy ich racjonalnego zagospodarowania. Pamiętnik Puławski 120 (2): 361-367.

Rola J., Rola H., Kucharczyk A., Latowski K., Borowiec S., Kutyna I. 1992. Występowanie wybranych gatunków chwastów w uprawach rolniczych - makroregion południowo-zachodni. Wyd. IUNG Puławy, R/292/3: 1-56.

Sekutowski T., Smagacz J. 2011. Podobieństwo glebowego banku nasion i aktualnego stanu zachwaszczenia w uprawie pszenicy ozimej. Journal of Research and Applications in Agricultural Engineering 56: 493-498.

Solarz W. 2007. Inwazje biologiczne jako zagrożenie dla przyrody. [Biological invasions as a threat for nature]. Progress in Plant Protection/Postępy w Ochronie Roślin 47 (1): 128-133.

Stuczyński T., Demidowicz G., Deputat T., Górski T., Krasowicz S., Kuś J. 2000. Adaptation scenarious of agriculture in Poland to future climate changes. Environmental Monitoring and Assessment 61: 133-144.

Stupnicka-Rodzynkiewicz E., Lepiarczyk A. 2004. Wpływ zmianowania, sposobu uprawy roli i herbicydów na bioróżnorodność zbiorowisk chwastów. Acta Scientiarum Polonorum, Agricultura 3 (2): 235-245.

Wesołowski M. 1984. Zawartość nasion chwastów w ważniejszych glebach makroregionu południowo-wschodniego i środkowego Polski. Roczniki Nauk Rolniczych, Seria A, 106 (1): 169-183.

Woźnica Z. 2008. Herbologia. PWRiL, Poznań, 430 ss.

Zawora T., Ziernicka-Wojtaszek A. 2005. Wpływ pogody i klimatu na działalność agrotechniczną i plonowanie roślin uprawnych na obszarze Polski. Problemy Ekologii 5 (53): 269-271. 